\title{
The importance of clonal selection of grapevine and the role of selected clones in production of healthy propagating stocks
}

\author{
Hajdu, E. ${ }^{1}$, Korać, N. ${ }^{2}$, Cindrić, P. ${ }^{2}$, Ivaniševic, D. ${ }^{2}$ \& Medić, M. ${ }^{2}$ \\ ${ }^{1}$ Corvinus University of Budapest, Institute for Viticulture and Enology, Research Station of Kecskemét; \\ H-6001 Kecskemét, PO Box 25, Hungary \\ ${ }^{2}$ University of Novi Sad, Faculty of Agriculture, Department of Fruit Science, Viticulture, Horticulture \\ and Landscape Architecture, SRB-21000 Novi Sad, Dositeja Obradovica Sq. 8.
}

\begin{abstract}
Summary: Genetical alterations and phytosanitary status promote the variability and modify the appearance of vine. Old vine varieties in old vineyards are highly variable and well adapted to selection. Clonal selektion is based on a visual performance: valuable individuals (clones) are picked out according to visible symptoms or characters. The genetical stability of clones is proved by testing the vegetatively propagated progenies on the basis of morphological and molekular (SSR, AFLP, SMPL, RAPD) markes.

Authors take great care of the visual phytosanitary selection as part of the clonal selection being the preliminary step to develop pathogen-free propagation stocks.

In Serbia (Vojvodina) the selection breeding has been carried on for several decades resulted in comparative clone trials with home and imported clones of Welsch Riesling, Chardonnay, Pinot gris, White Riesling. Among the clones of home selection SK.54 Welsch Riesling clone is the most valuable. Its clearing from pathogene is being carried on in an interregional IPA programme (HUSRB/0901/214/123) in Kecskemét.

In Kecskemét, the centre of the Hungarian Danube vine region 5 vine clones have been registered (Cegléd szépe K.73, Irsai Olivér K.11, Kövidinka K.8, Hárslevelü K.9, Pannónia kincse K.56). Besides them 18 virus-tested clones have also been qualified. Works aiming at their complete exemption are going on in order to obtain clones free of propagation wood-borne diseases.
\end{abstract}

Keywords: clonal selection (genetical and phytosanitary), clone, distribution curve, mutation, performance test, selection progress, Vitis vinifera L., propagation wood-borne diseases

\section{Genetical variations in vine (mutation)}

Living creatures on Earth are exposed to selection pressure and can only survive if they are capable to accustom to circumstances, otherwise, they degenerate and perish. The grapevine (Vitis vinifera L.) itself is cultivated for several thousand years old and extremely variable in form (Fig. 1, 2). Variation is caused by mutation and/or chronic diseases.

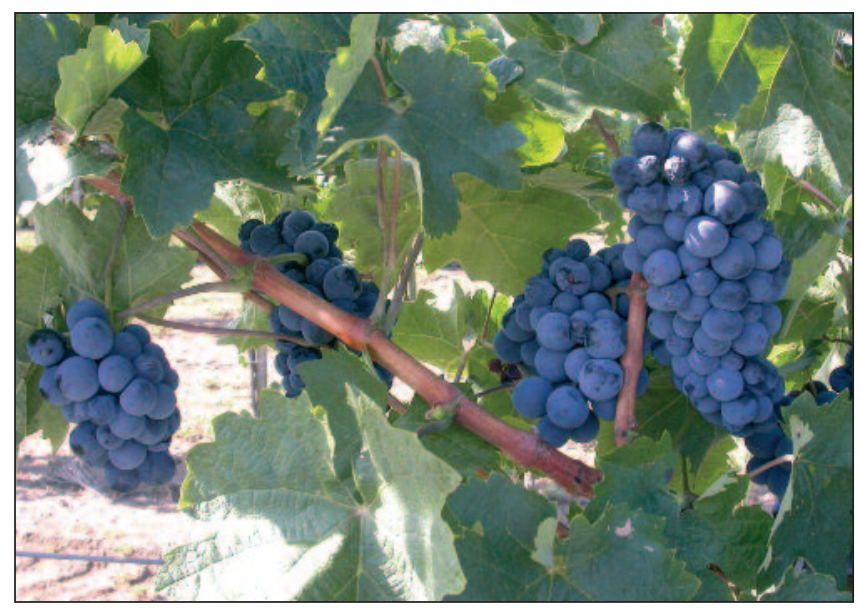

Fig. 1. Kadarka with little grapes and bigger berries

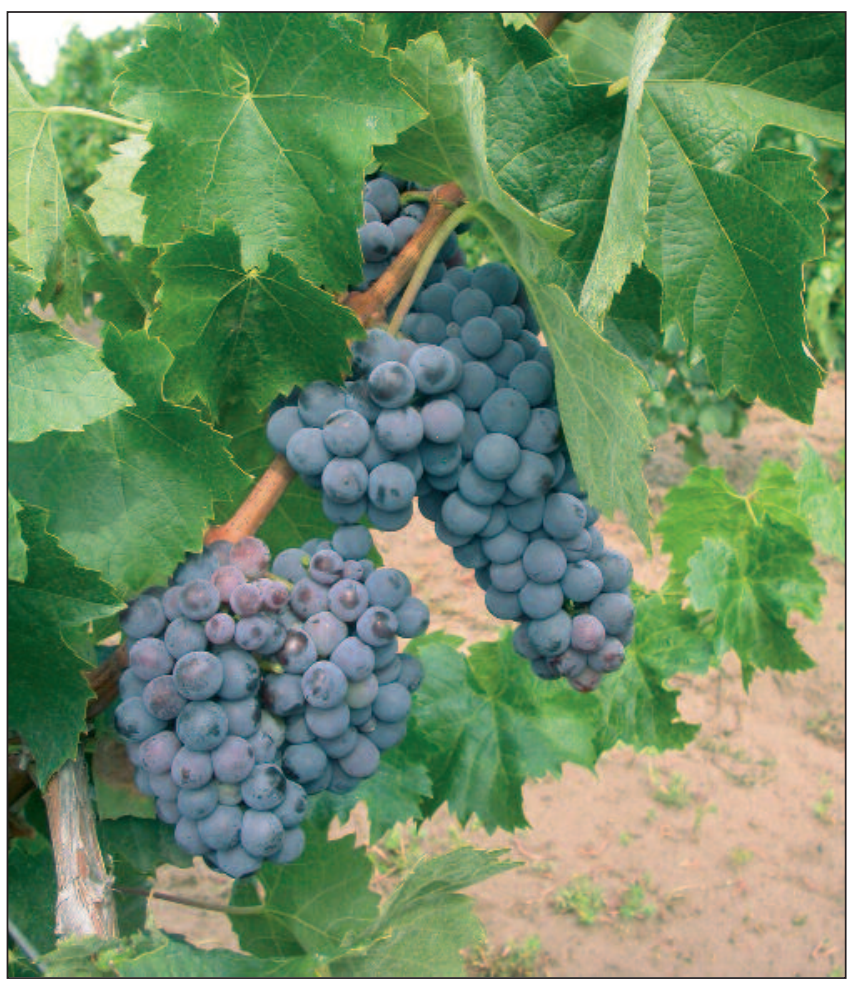

Fig. 2. Kadarka with bigger grapes and little berries 


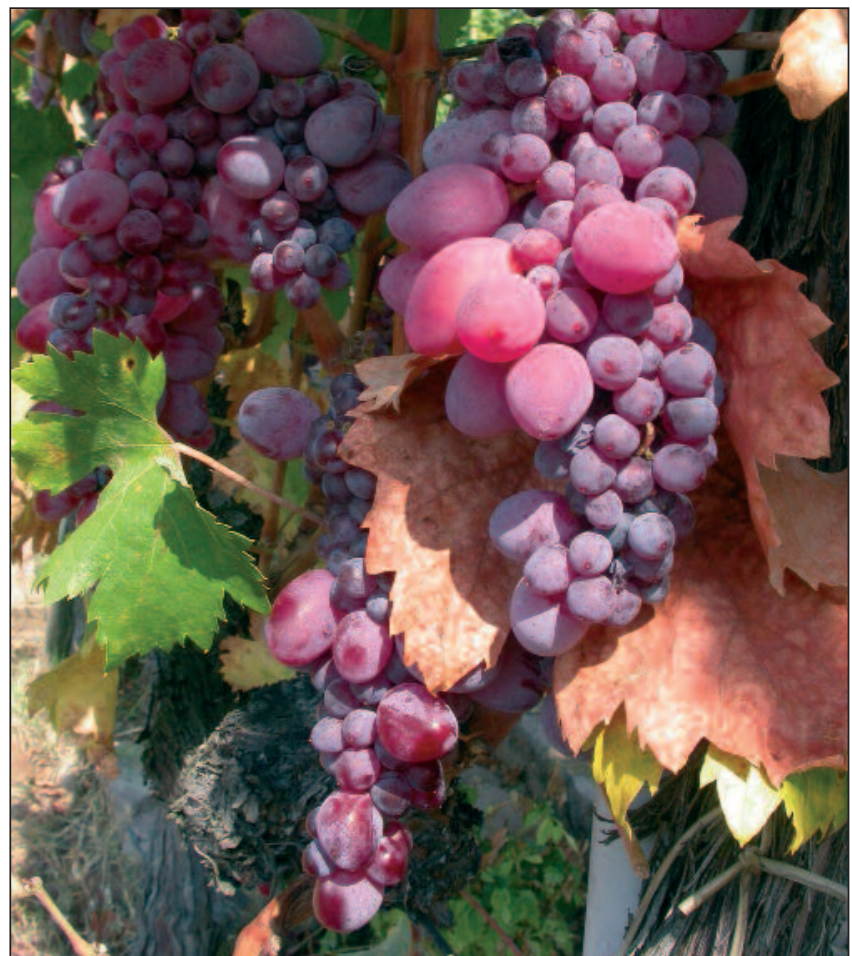

Fig. 3. Millerandage on clusters

Darwin and Hugo de Vries explained the high variability, which serves as base for selection, by mutation. According to Rédei (1987) "mutation produces a variety sortiment of which evolutionary forces choose the most capable ones to comply with modified surroundings". Mutation is caused by external effects (light intensity, UV-B radiation, heat, water supply, nutrient regimes, competition for light, water and nutrients in the ecosystem. Comprehensive description of mutation in vine is found in Steingruber (1933), Kozma (1957), Németh (1958), Luntz (1962), Bakonyi (1968), Ivanov et al. (1970), Calo et al. (1978). These include vigorous and weak growth, hermaphrodite and abnormal flower types, even and sliced leaves, diploid and tetraploid chromosome numbers, full clusters and millerandage (Fig. 3). According to Bögre \& Dolhy (1992) mutation frequency is also determined by DNA in the cell mitochondria. Hoffmann et al. (2009) considered retrotransposition within the vine genome as an important source of variation. Stenkamp et al. (2004) used molecular and histological methods to detect chimera cells due to mutation and which can be discerned according to genotypes. Nowadays research teams are working to prove genetical variability in vine. The genetical background of variations in native vine varieties is determined by SSR, AFLP, SAMPL and M-AFLP methods also contributing to the success of clonal selection (Cretazzo et al., 2010; Loureiro et al., 2011). Castro et al. (2009) used the RAPD method with 51 "primer" in 59 clones of 3 vine varieties and differentiated 45 clones according to different genotypes. It confirmed the is genetic difference among clones. Somaclonal variability can, however, occur in in vitro cultures which could increase the genetical variability of in vitro plants/clones (Butiuc-Keul et al., 2009).

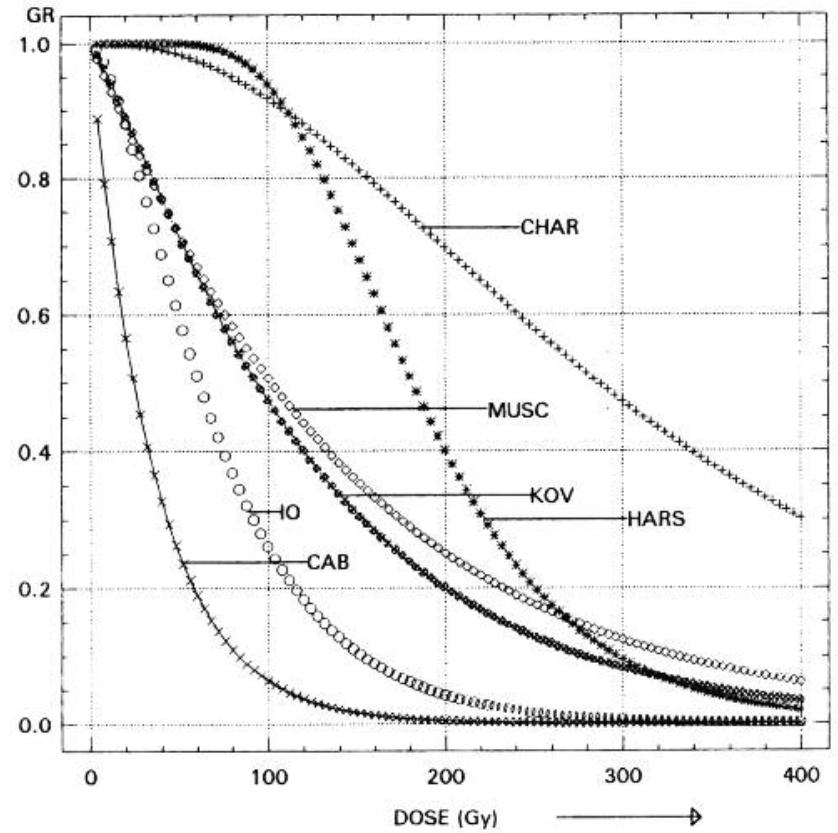

Fig. 4. Model of $\chi$-ray sensitive at the studied vine varieties (clones) MUSC $=$ Muscat ottonel clone type

$\mathrm{KOV}=$ Kövidinka K.8

$\mathrm{IO}=$ Irsai Olivér K.11

$\mathrm{CAB}=$ Cabernet Sauvingon E.153

HARS = Hárslevelü K.9

$\mathrm{CHAR}=$ Chardonnay clone type

Vine varieties react differently to stresses as mutation effects. For example Cabernet sauvignon is relatively stable while Hárslevelü is very sensitive to $\chi$-ray (Hajdu \& Körösi, 1992) (Fig. 4).

\section{Morphological variations caused by pathogens}

Beside genotypic changes (mutation) phytophysiological disorders caused by diseases and inadequate nutrition are also responsible for the variability and decay of stand of stocks. Several authors, like Lehoczky (1968), Brückbauer \& Rüdel (1971), Malenin (1971), Bovey et al. (1973, Legin (1973), Scarabelli et al. (2003), Schöffling and Stellmach (1993), Calo (1987) dealt mostly with diseases caused by viruses and viroids. In the same time Fischer (2006) summed up the fungi transferred by propagation wood and causing ESCA as found in the xylem. These parasites cause severe damage and even death by feeding on the cells. Viruses have been known for a long time but studies and selection only began in the XIX. century (Valet, 1973). Up to the 1960s our knowledge of them was very poor. Today considerable information has accumulated concerning viruses, viroids, bacteria, mycoplasma, fungi and the diseases caused by them in different parts of the vine. Viruses play an important part in rootstocks. However, as they are mostly latent they are hardly observable and the apparantely symptomless but infected rootstocks can easily infect the scion (Becker, 1990; Bleser et al., 2004).

By now, we have possess very good and reliable labor and field test methods to detect propagation wood-borne pathogens following visual selection: testing green and 
woody parts, serological tests, ELISA, molecular methods (PCR), etc. The disinfection of infected but otherwise valuable clone propagation wood is aided by heat therapy, in vitro propagation, embryo and meristem cultures.

In Hungary organized virus diagnosis and disinfection began in the Research Institute for Viticulture and Enology in Kecskemét (Miklóstelep) in 1970 under the direction of János Lehoczky. As a result basic vineyards including 76 vine varieties/clones were established on more than 100 ha.

Nutritional disorders and nutrient deficiencies (Fe, K, Mg, $\mathrm{Zn})$ also contribute to the sensitivity to varions diseases of the stock (Currle et al., 1983; Hajdu, 2011). Scrabelli et al. (2003) tested 115 clone candidates of the variety Vermentius and found differences in the rate of infection by the different viruses. They attributed it to nutritional differences in the clones.

\section{Propagation wood-borne parasites}

1. Viroids

2. Viruses: GFLV (Grapevine fanleaf virus)

ArMV (Arabis mosaic virus)

GLRaV-1,5 (Grapevine leafroll-associated virus)

3. Mycoplasma (Flavescens Dorée) (Fig. 5)

4. Bacteria (Agrobacterium tumefaciens /Smith et Town./ Conn)

5. Mycosis: fungi living in the xylem, pathogens of ESCA disease (Fischer, 2006)

\section{Fomitiporia mediterranea}

Phaecomoniella chlamydospra

Phaeoacremonium aleophilum

Phomopsis viticola

Botryosphaeria sp.

Eutypa lata

Eutypa armeniaceae

6. Nutritional disorders (Fe-, K-, Mg-, Zn- etc. deficiency) (Fig. 6)

7. Symptoms caused by above parasites:

stock: abnormal growth, few canes, decay

root: poor root growth, air roots on the place of grafting

trunk: tumor, flattening, abnormal rind development shoot and cane: forked branching, stem flattening, short internodes, double buds, insufficient cane maturity

leaf: panasure, mosaic discoloration, yellowing along the veins, vein necrosis, enation, leafroll, total or partial yellowing of the leaf blade, drying

flower: sexual defect, insufficient set (drop off, millerandage)

yield: low cluster yield, abnormal cluster and berry development, low quality value, deformation, tendril atrophy, breaking of cluster stem, berry scattering

seed: deformation, loss of germination ability, tissue prolification

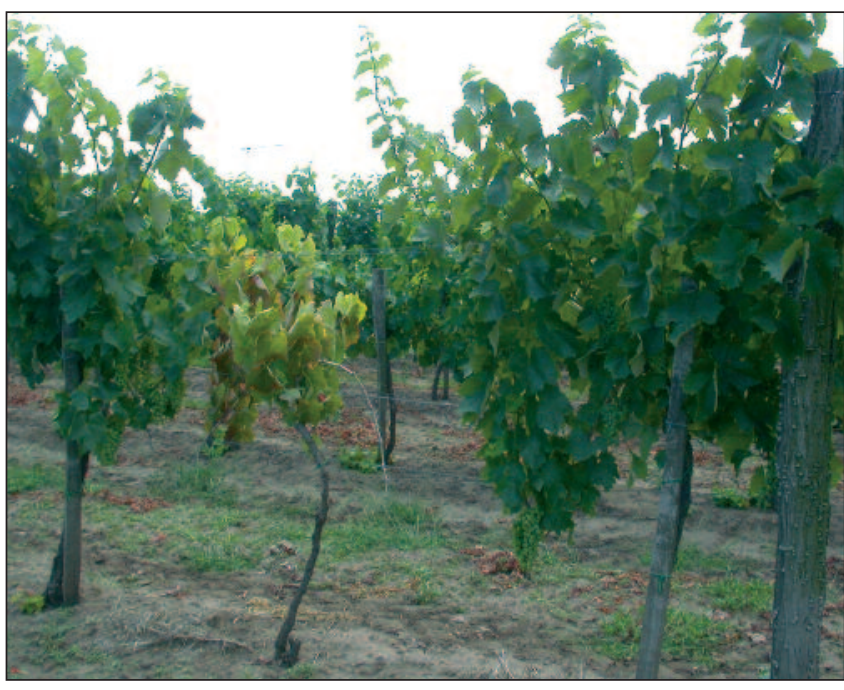

Fig. 5. Diseases stock (Fitoplasma)

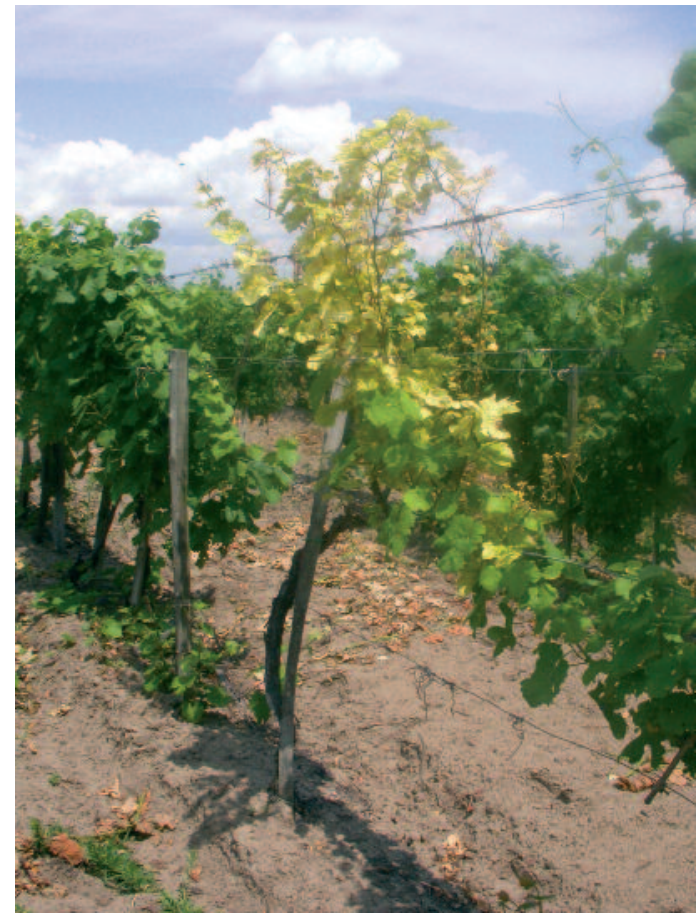

Fig. 6. Iron deficiency

\section{The importance selection}

In vine regions of the world, selection has always been a successful breeding method. Clonal selection is a means of intensive improvement successfully adapted in several varieties (White Riesling, Muscat d'Adda, Pinot sp., Steinschiller, Hárslevelü, Welsch/Italian Riesling, Müller Thurgau etc.) (Németh, 1958; Becker \& Sievers, 1978; Cindrić, 1981; Bleser et al., 2010).

German, French and Italian breeders excelled in clonal selection in Western Europe (Hajdu, 1993). In Germany, the consequent clonal selection average yield from $56,97 \mathrm{hl} / \mathrm{ha}$ in 1951-1960 to 94,71 hl/ha in 1964-1973 (Becker, 1990; Bleser et al., 2004). Similarly good results were obtained in France 
(Valat, 1975) and Italy (Calo et al., 1978). Later the individual selection method was used in Australia, too. It can be read at Cirami (1987). Wine grapes have been cultivated in Australia for 175 years but clonal selection was only introduced in the 1950s in Barossa Valley on 600 ha.

According to Schöffling and Stellmach (1993) selection is one of the methods to maintain variety. If variety maintenance concerns one plant it is clonal selection. In the same time, clonal selection is a controllable and systematical method where the clone preserves its type and performance. Selection is adapted to pick out varieties in a mixed plantage or clones within a variety (Loureiro et al., 2011).

Clonal selection is time consuming (15-20 years). Thus, according to Kiss (1990) it should only be applied for promising varieties much wanted on markets and grown on large areas. It would be nonsense to propagate varieties which are not wanted and are losing markets. Accordingly the necessity of selection is not only determined by genetical, biological or cultural values but also by market demands, whether rootstock, table or wine grape varieties. The aim of selection depends on the utilization of the variety and market conditions. In rootstock varieties Rouget (1978) stressed tolerance to lime, drought, salts, surplus or deficiency of nutrients and resistance to Phylloxera and nematodes.

In table grape varieties great importance is attributed to early ripening, external appearance of clusters, big clusters, big and uniform berry size, nice color, bloom and excellent flavor.

In wine grape varieties breeding aims at improving qualitative and quantitative characters (fertility, resistance to biotic and abiotic factors, pigment content in berry skin and aroma).

\section{Selection methods}

In viticulture mass, clone type and clonal selections are known. clonal selection is composed of 2 parts: genetical selection and phytosanitary selection (Fig. 7).

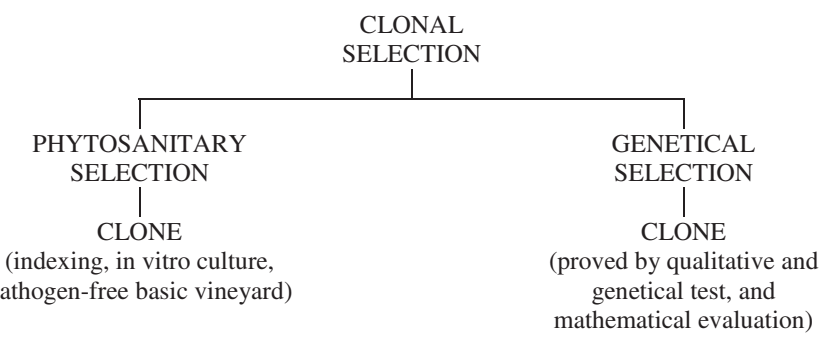

\section{Genetical selection}

In the genetical selection positive variants, mutants, chimera are looked for which can be verified in cells by microbiological methods (Stenkamp et al., 2004).

In individual or clonal selection (Table 1) the performance of stocks is evaluated during several asexual propagations which allow conclusions as to the clone value of the chosen mother stock. Considerable selection progress can be achieved $\mathrm{S}_{\mathrm{H}}=\mathrm{S}_{1}-\mathrm{S}_{0}$ (where $\mathrm{S}_{\mathrm{H}}=$ selection progress; $\mathrm{S}_{0}=$ unselected population; $\mathrm{S}_{1}=$ performance of the selected clone for a given character) when the clone value is genotypically fixed, that is, meaning mutation and not modification.

In the vine regions along the Hungarian-Serbian border selection breeding got a new impulse after the II. World War (Fig. 8). Professor Pál Kozma introduced the mass and clonetype selection methods in varieties grown on large areas (Furmint, Kadarka). In order to obtain early results he worked out a clone-type selection method based on flower biology. Márton Németh an ampelograph, worked out and applied a IV. step clonal selection method which was later reduced to III. step by Ottokár Luntz (Fürt et al., 1982; Hajdu, 1989, 1990, 1993). In the vine region along the Hungarian-Serbian border the IV. step clonal selection of Németh was used to improve the vine varieties (Füri \& Németh, 1972; Becker-Sievers, 1978; Schöffling-Stellmach, 1972). The work was directed in the Research Institute for Viticulture and Enology in Kecskemét by József Füri and Edit Hajdu.

On the other side of the border in Vojvodina work began in Sremski Karlovci at Novi Sad in 1970 with the variety Welsch (Italian) Riesling by combining the German and Hungarian methods under the leadership of Professor Petar Cindriæ. This method is essentially an individual or clonal selection method (Cindrić, 1981; Cindrić, et al., 1987).

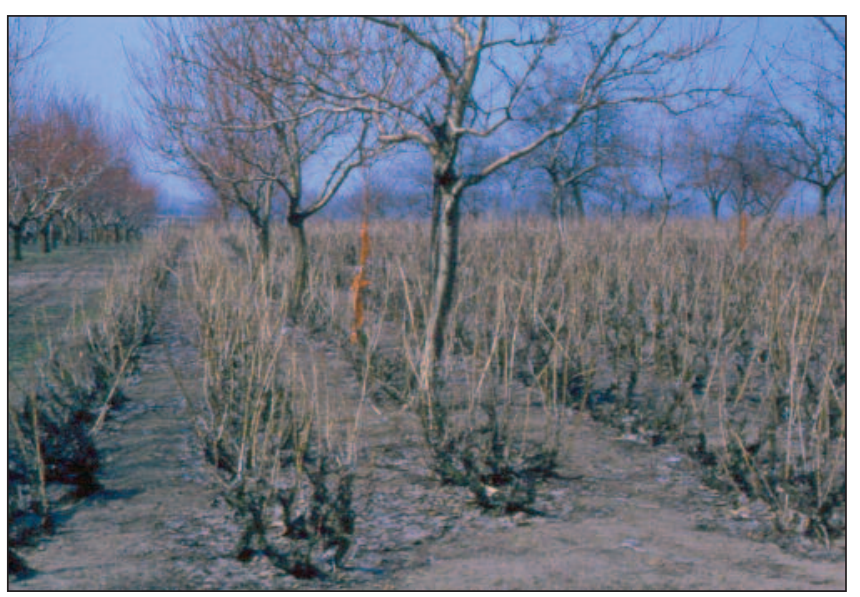

Fig. 8. Old vineyard for clonal selection

\section{Phytosanitary selection}

The performance of a clone is accentuated by its sanitary condition (Hartmair, 1973; Kontic et al., 2009). In this selection the sanitary condition of mother stocks is evaluated at least twice a year, in June and in September. This selection precedes cleansing of infection and requires a high degree of know-how because symptoms, due whether to abiotic (hail, frost, sun, burn, nutritional disorders, excess chemical doses) or biotic (diseases, pests) stress effects, must be correctly recognized. It is imperative to have a throughout knowledge 
Table 1. IV. step clonal selection method of Németh

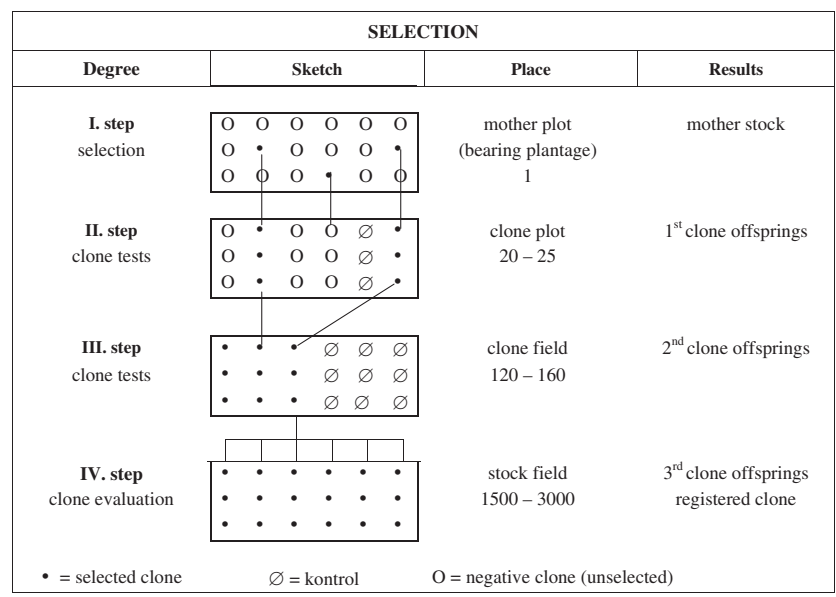

of the variety and the typical features of the environment. Virus concentration in the cell can depend on local conditions. For example: in Croatia more viruses were selected in the same variety in the southern part of the country than in the norther part (Kontric et al., 2009). Susceptibility to diseases can also help breeders in visual selection. For example: Cegléd szépe is susceptible to GFLV virus, Hárslevelü to GLRaV, Jubileum 75 to tendril atrophy, Kadarka to tor, Welsch (Italian) Riesling to Mg-deficiency, Pannónia kincse to flower set and several table grape varieties to Agrobacterium.

Phytosanitary selection begins with the marking of diseased stocks, pre-pruning and exclusion from further propagation by eliminating the trimmings, cleaning of propagation wood from healthy clone stocks and the establishment of pathogen-free stocks where propagation wood can be purchased officially.

The phytosanitary selection is a visual selection, a means by which diseased individuals with negative characters can be eliminated, the expansion of diseases can be hindered and plants less susceptible to diseases can be chosen.

\section{The clone}

The term "clone" was created by Webber in 1903 . Etymologically it comes from the Greek word "klon" (shoot) which derives from the word "klan" (dissect). Since 1910 it has generally been accepted in breeding (Stellmach, 1972).

In practical selection the clone is the offspring of a single stock, a plus variant biotype of the variety (Bakonyi, 1968; Pétervári, 2000). Särtorius (1928) was the first who recognized the special values of clones in Germany.

The clone remains constant as long as no further mutation takes place. The clone value of vine stocks is only valid for a certain period; when conditions induce a new mutation, new selection is needed (Becker, 1990).

In the last 100 years research technology concerning the laying of foundation of theoretical selection has developed quite suddenly. In 1888 Goethe still thought the bud to be the smallest plant part capable to mutate and be propagated (Becker, 1990). About 100 years later the French breeder
Bouquet (1989) indicated the cell as the smallest unit which can be regenerated. It can also be a somaclone and regenerated in vitro. Somaclonal variability and genetical stability, respectively, can be checked by molecular markers (RAPD, SSR, AFLP, M-AFLP, SAMPL) (Craciunas et al., 2009; Cretazzo et al., 2010).

Clones play an important part in vine evolution. The propagation of clones increases the performance of the plantage but improverishes its genestock. In order to compensate for this effect several clones, instead of one, should be selected and cultivated. In respect of evolution the ecovalence of clones has high importance to enable their profitable cultivation in large extent.

A high degree of adaptability is required when clones are to be produced in large geographical regions (such is the clone White Riesling Gm.239). One should be aware of the dependence of clones from environment and their phenotypic stability. Bálint (1976) stated that the appearance and form of mutation could indicate the tendency between environmental factors and their correlations. According to the decree O.I.V. VIII. 6/90 environmental effects are more important than clone effects in a given location. Clones should be cultivated in the region were they were selected.

The increased biopotential of a clone is a great help to establish pathogen-free vineyards for further propagation.

The clone is a means in standard viticulture in every part of the world. It is cheaper to exploit its high biological and genetical capacity than to apply noxious fertilizers in high doses.

A qualified clone must be marked. For example: Rhine Riesling Gm.239-17, where the letters after the name Gm (Geisenheim) indicate the site of selection; the first figures, 239 , the clone and the following figures, 17 , the subclones obtained from further selections.

\section{Results}

The vine varieties cultivated on large areas between the Danube and the Tisza along the border have been selected by Serbian and Hungarian breeders. Nearly the same methods were used in Novi Sad (Sremski Karlovci - SK) and Kecskemét (K). In the long-term trials clones imported from abroad were used for control and the unselected basic population for standard.

\section{Results achieved in Vojvodina}

In the whole Carpathian Basin as well as in the region of Bácska Welsch Riesling is the most widely cultivated white wine variety. Several valuable clones were selected in Vojvodina as well as in Hungary. From both sites the most valuable clones, Welsch Riesling SK.54 (Fig. 9) and Welsch Riesling B.20 were compared (Table 2). Data including 13-14 years show considerable selection progress. Both clones surpassed the performance of the unselected basic population by $10 \%$ for several characters and by more than $30 \%$ for yield. In the same trial the Hungarian clone Pinot 
Table 2. Performance of "Olasz rizling" clones

\begin{tabular}{|l|c|c|c|c|}
\hline \multicolumn{1}{|c|}{ Characteristics } & $\begin{array}{c}\text { Basic } \\
\text { population } \\
\text { (unselected) }\end{array}$ & $\begin{array}{c}\text { Serbian clone } \\
\text { SK.54 }\end{array}$ & $\begin{array}{c}\text { Hungarian } \\
\text { clone } \\
\text { B.20 }\end{array}$ & $\begin{array}{c}\text { Difference } \\
\%\end{array}$ \\
\hline Time of trial & $1988-2000$ & $1988-2000$ & $1984-1998$ & - \\
\hline Yield $\left(\mathrm{kg} / \mathrm{m}^{2}\right)$ & 1,20 & 1,59 & 1,63 & $+32 ;-36$ \\
\hline Cluster $(\mathrm{g})$ & 141 & 161 & 191 & $-14 ;-36$ \\
\hline Sugar content in must $\left(\mathrm{Mm}^{\circ}\right)$ & 19,7 & 21,6 & 18,3 & $+10 ;-7$ \\
\hline Acid content in must $(\mathrm{g} / \mathrm{l})$ & 7,2 & 7,0 & 7,7 & $-3 ;+7$ \\
\hline Botrytis infection $(\%)$ & 10,4 & 11,2 & 10,5 & - \\
\hline Harvest time & Oct. 2. & Oct. 2. & Oct. 3. & \\
\hline
\end{tabular}

Place of trial: Sremski Karlovci (Serbia)

Spacing: $3,0 \times 1,2 \mathrm{~m}$

Olasz rizling $=$ Welsch Riesling $=$ Italia Riesling

Table 3. Performance of "Pinot gris" clones

\begin{tabular}{|l|c|c|c|c|}
\hline \multicolumn{1}{|c|}{ Characteristics } & $\begin{array}{c}\text { Basic } \\
\text { population } \\
\text { (unselected) }\end{array}$ & $\begin{array}{c}\text { Serbian clone } \\
\text { SK.54 }\end{array}$ & $\begin{array}{c}\text { Hungarian } \\
\text { clone } \\
\text { B.20 }\end{array}$ & $\begin{array}{c}\text { Difference } \\
\%\end{array}$ \\
\hline Time of trial & $1981-2000$ & $1981-2000$ & $1981-2000$ & - \\
\hline Yield $\left(\mathrm{kg} / \mathrm{m}^{2}\right)$ & 0,64 & 0,93 & 1,04 & $+45 ;+62$ \\
\hline Cluster $(\mathrm{g})$ & 88 & 107 & 122 & $+22 ;+39$ \\
\hline Sugar content in must $\left(\mathrm{Mm}^{\circ}\right)$ & 21,4 & 21,8 & 22,0 & $+2 ;+3$ \\
\hline Acid content in must $(\mathrm{g} / \mathrm{l})$ & 7,3 & 8,1 & 7,2 & $+11 ;-1$ \\
\hline Botrytis infection $(\%)$ & 3,6 & 4,9 & 11,8 & - \\
\hline Harvest time & Sept. 19. & Sept. 18. & Sept. 22. & \\
\hline
\end{tabular}

Place of trial: Sremski Karlovci (Serbia)

Spacing: $3,0 \times 1,2 \mathrm{~m}$

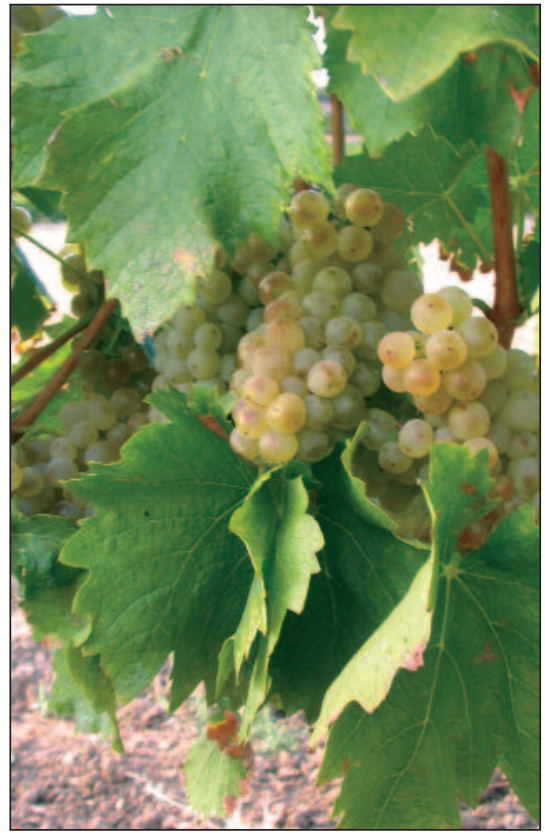

Fig. 9. Welsch Riesling SK.54

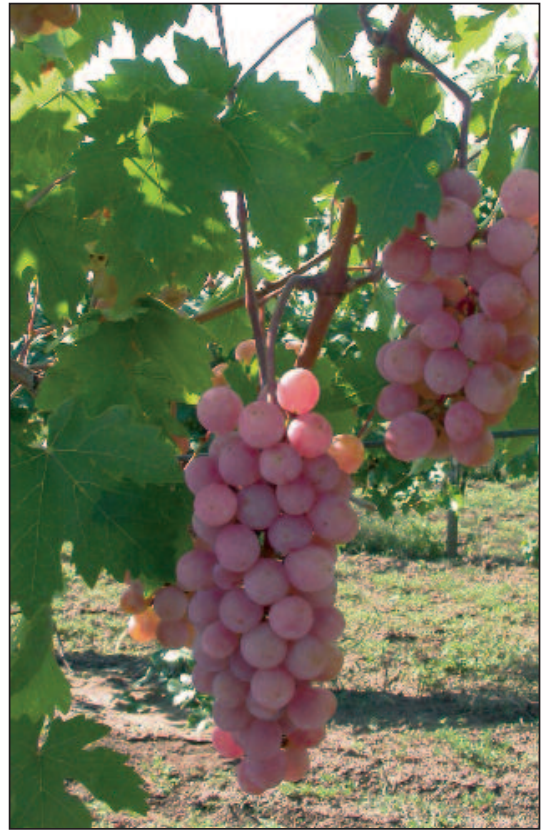

Fig. 10. Cegléd szépe K.73 gris B.10 and the German Clone, Pinot gris Gm.2-54, were also tested. Similar selection progress could be observed: the clones proved superior to the unselected basic population by 22-62\% mostly for quantitative characters (Table 3).

White Riesling and Chardonnay clones were also evaluated. The Italian Chardonnay VCR. 4 and the French Chardonnay 75 were tested side by side. The French clone surpassed cluster yield by $83 \%$ and cluster size by $57 \%$ as compared to the Italian clone. The German clone White Riesling Gm.2-54 was studied in relation to the unselected basic local population. Yield increased by $55 \%$ in relation to the unselected stocks.

\section{Results achieved in Kecskemét}

In the Research Institute for Viticulture and Enology several table grape and wine grape varieties have been selected for several decades. From the tested and most valuable clones 2 table grape clones (Cegléd szépe K.73 and Pannónia kincse K.56) (Fig. 10, 11) and 3 wine grape clones (Hárslevelü K.9, Irsai Olivér K.11 and Kövidinka K.8) (Fig. 12, 13, 14) were registered. They serve to establish virus-tested stock vineyards for propagation.

The clonal selection of Muscat Ottonel started about 20 years ago (1990). Among the clones differences were observed in cluster type and size. There are clones with cylindric, shouldered clusters and others with sideclusters (Fig.15).

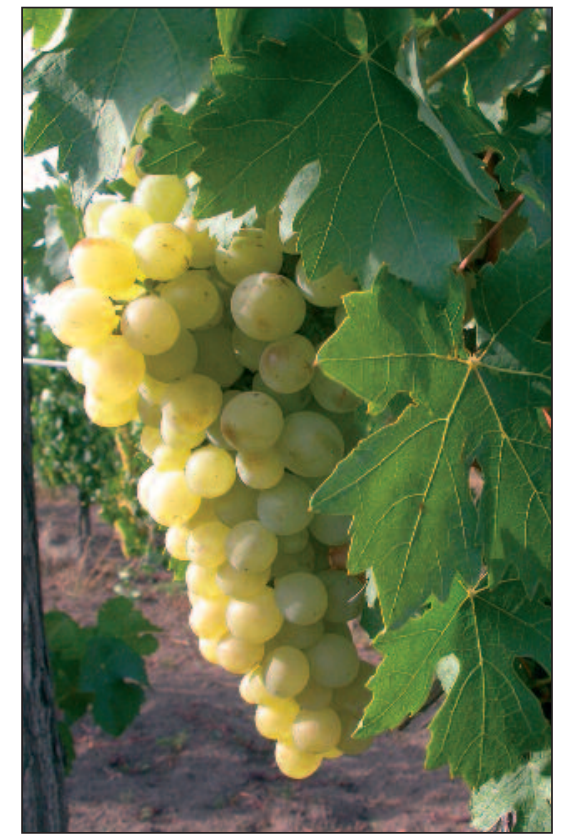

Fig. 11. Pannónia kincse K.56 


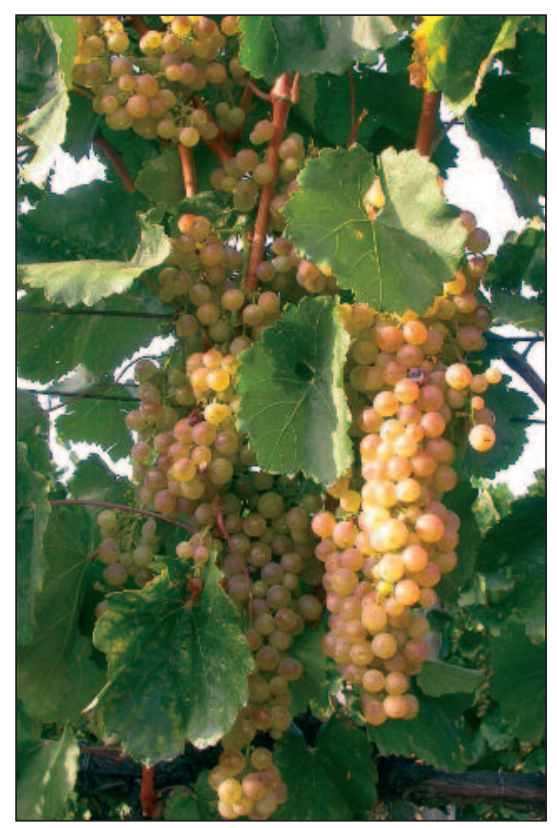

Fig. 12. Hárslevelü K.9
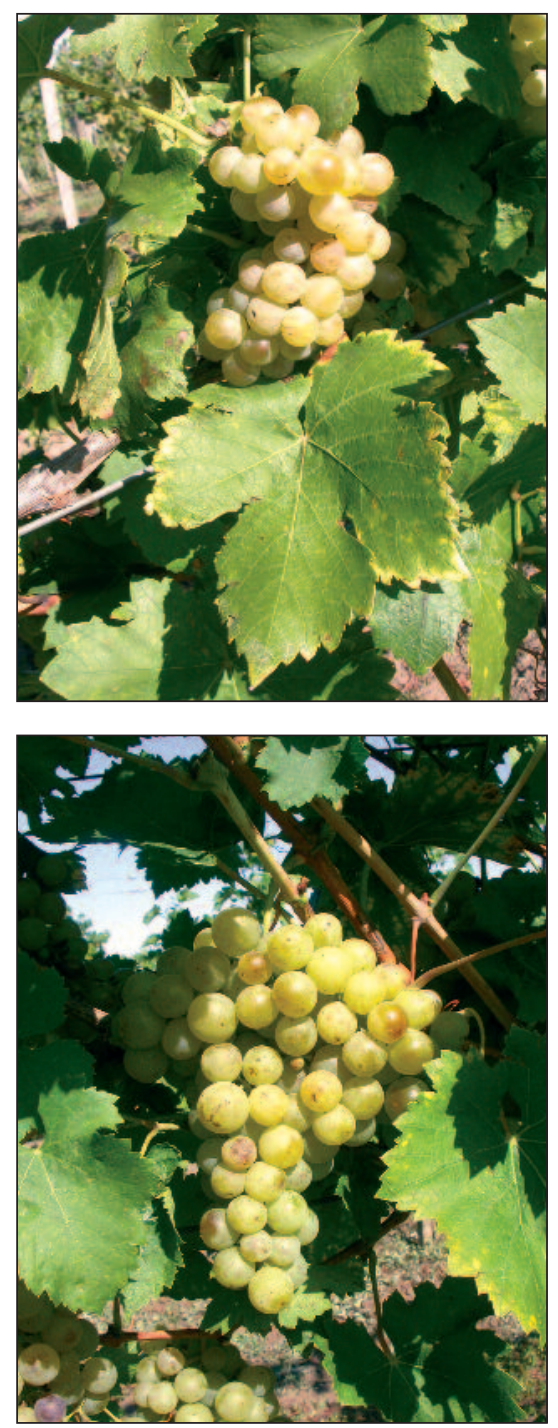

Fig. 15. Cluster types of Muscat ottonel clones

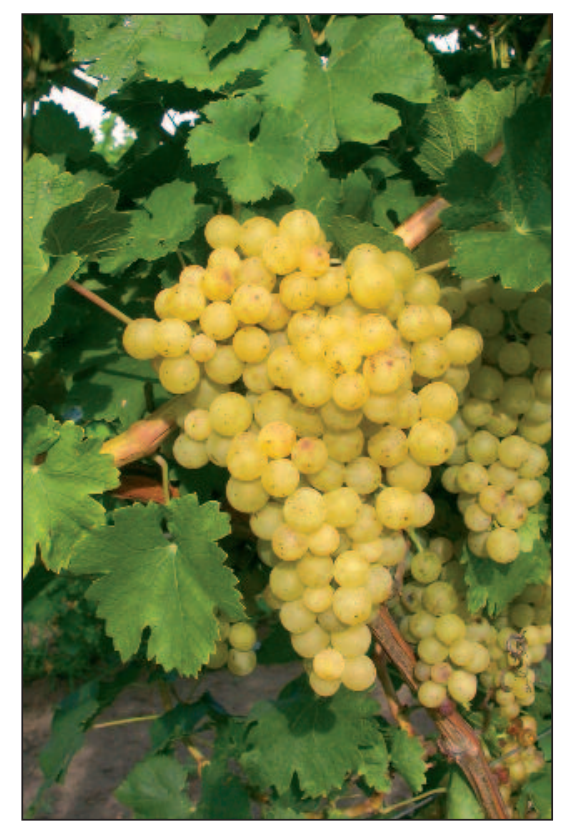

Fig. 13. Irsai Olivér K.11
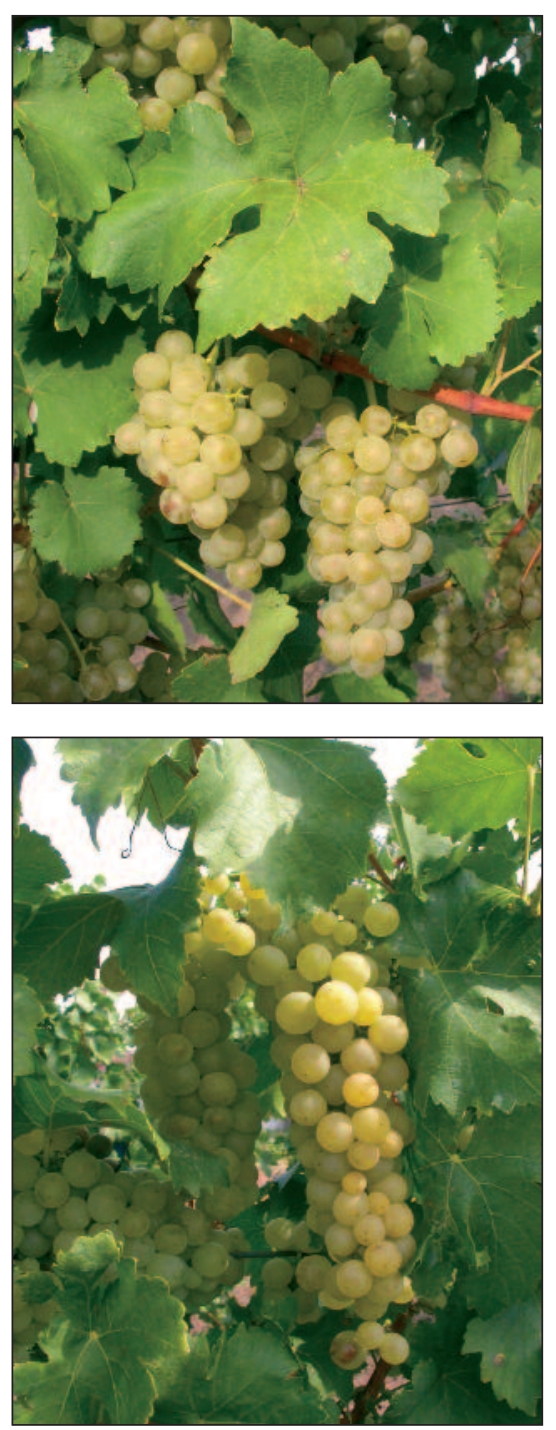

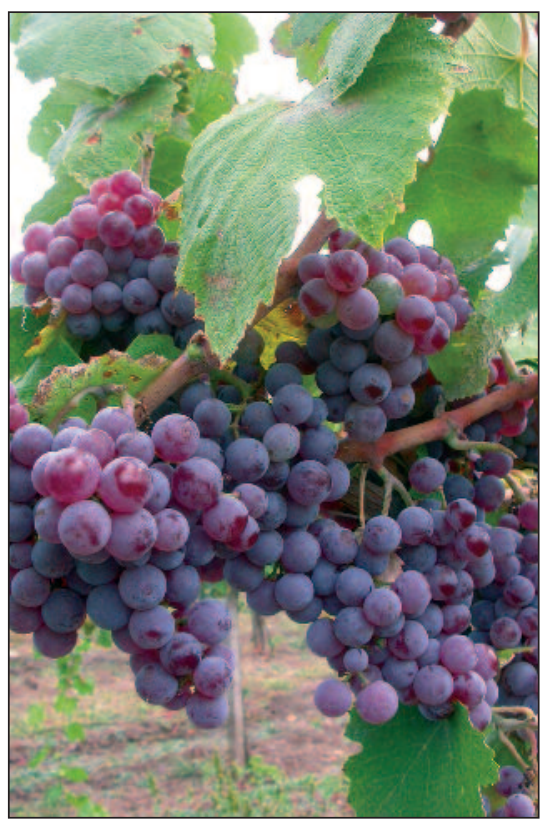

Fig. 14. Kövidinka K.8
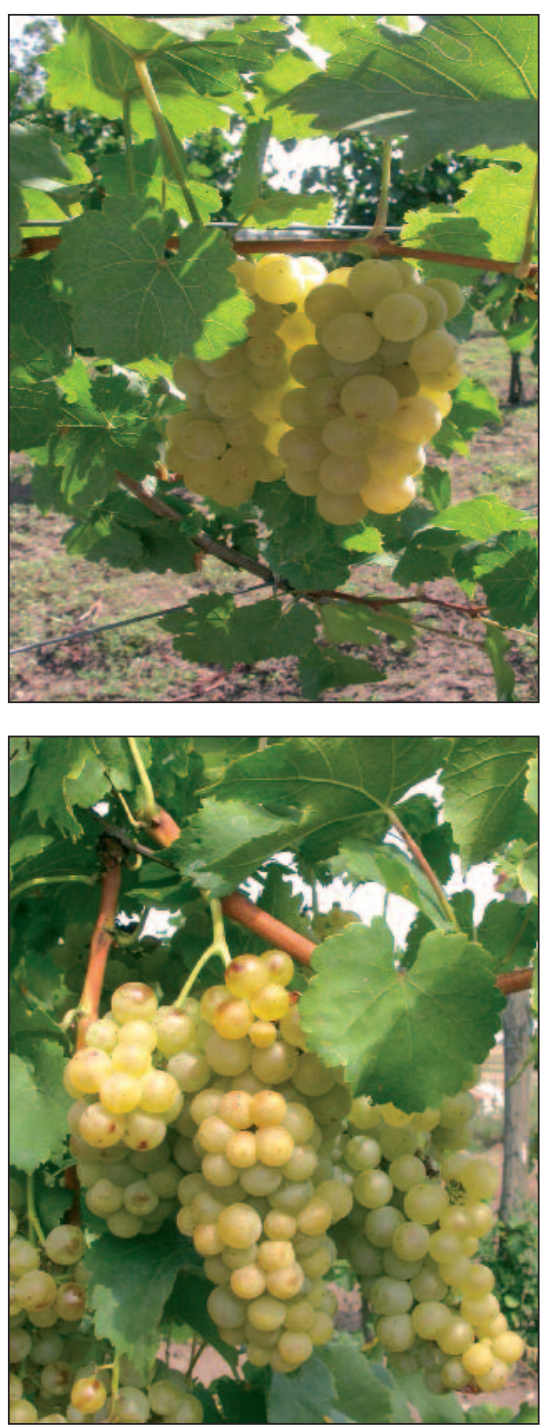

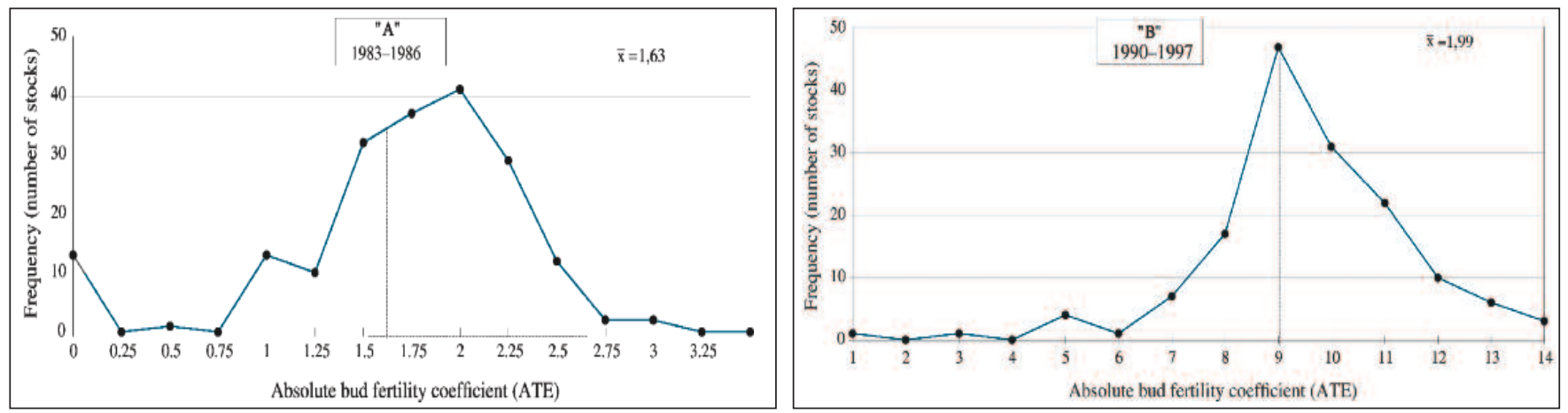

Fig. 16. Frequency distribution of mother stocks according to their bud fertility Muscat Ottonel

Clone performance and the frequency distribution of the clone population were tested for different characters. Fig. 16 shows the distribution of fertility coefficients (ATE) in buds in 2 sites. "A" in Harta is the distribution curve of mother stocks selected from the basic population according to absolve fertility coefficient. " $\mathrm{B}$ " in Kecskemét is the distribution of absolute fertility coefficient of the same mother stock after their removal to this site. The difference is caused by the different sites. At both sites distribution is normal, ATE values surpass 1,50 which means considerable selection progress for Muscat ottonel. The narrower the distribution curve the more stable and uniform the genetic determination of the clone. Diverging curves mean high environmental variance.

From the table grape varieties the clone Pannónia kincse K.56 was tested for clusters and berry number and weight. Data were used to calculate the weight $(\mathrm{g})$ distribution within clusters. Fig. 17 shows differences in berry number and weight within a valuable clone. It is evident that proper summer pruning is necessary in selected clones in order to assert its genetical ability, that is, to produce big and uniform clusters and berries.

Beside the genetically selected and virus-tested clones, 15 virus-free and tested clones were also qualified (Fig. 18). They are available in a pre-basis stock vineyard at the Research Institute for Viticulture and Enology in Kecskemét.

In the frame of a Hungarian-Serbian cross IPA trial programme a team was organized to free the propagation wood of vine varieties bred in the Vojvodina

\section{1. cluster}
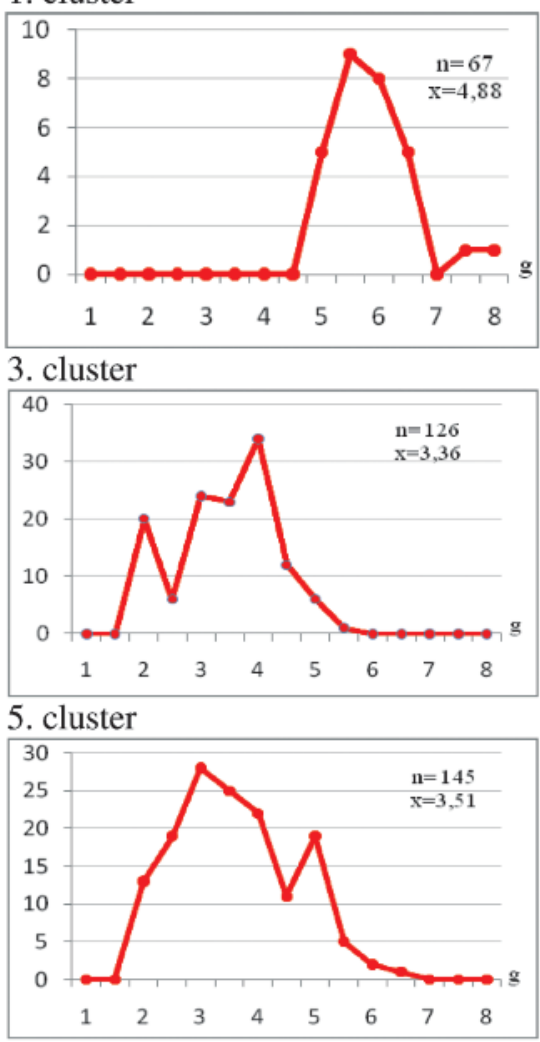

7. cluster

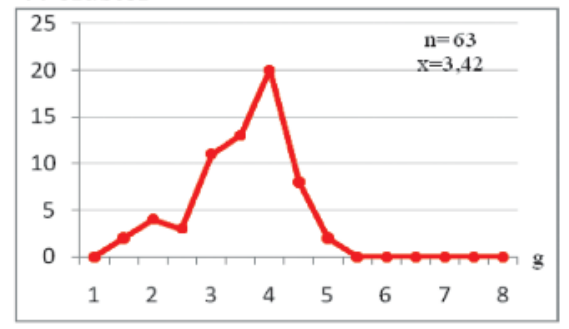

9. cluster

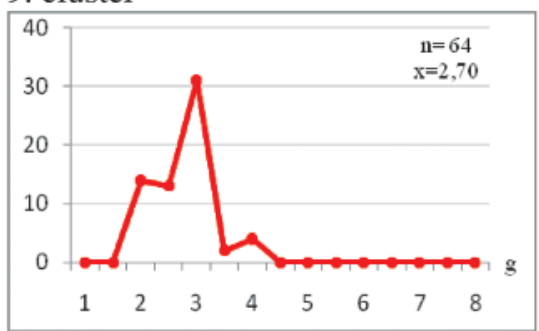

Fig. 17. Weight distribution/cluster (g) of Pannónia kincse

\section{2. cluster}

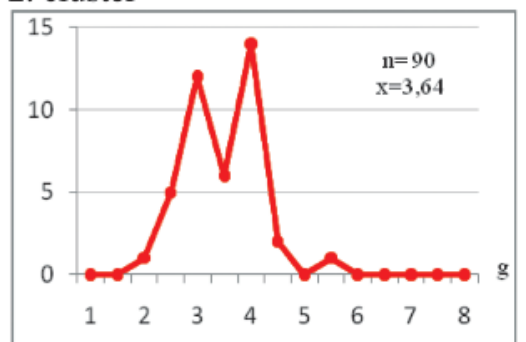

\section{4. cluster}

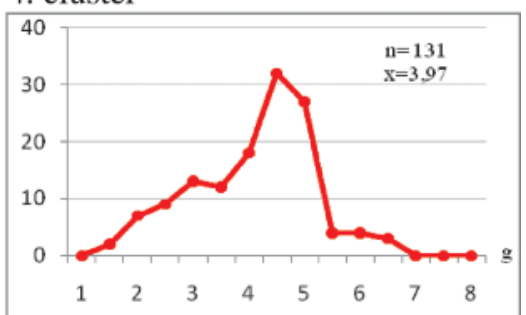

6. cluster

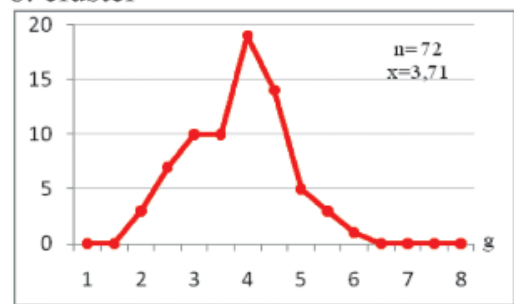

\section{8. cluster}

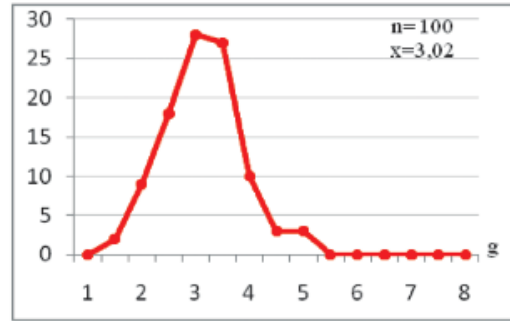

10. cluster

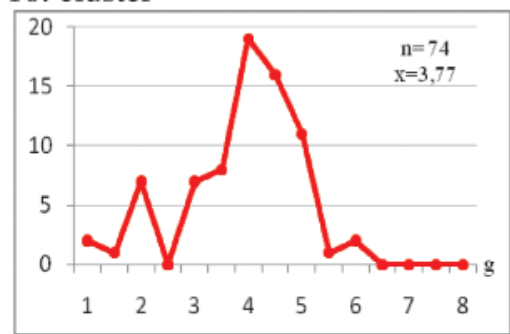




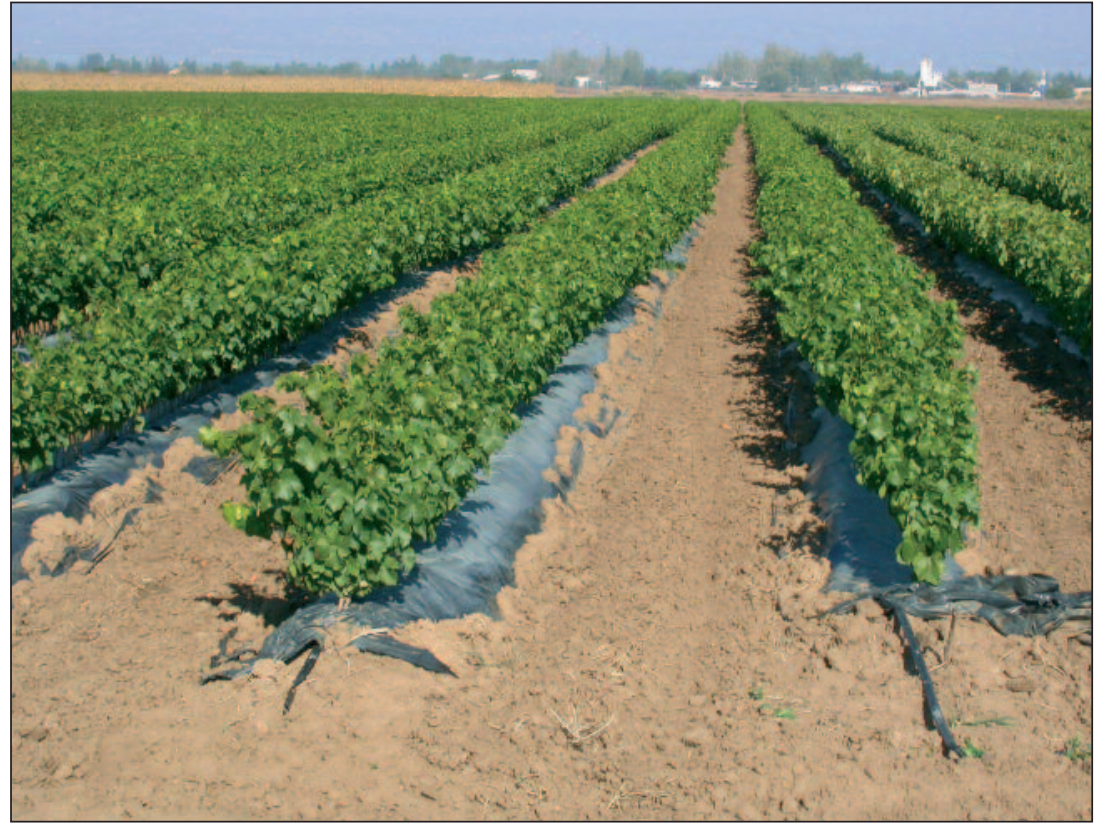

Fig. 18. Qualified grafted clones in nursery

and county Bács from pathogens. Plants obtained from the cooperation will be used to establish basis vineyards where propagation can start to supply growers and propagators.

\section{References}

Adriana, C., Camelia, P., Emilia, V., Cezarina, N. \& Jordache, S. (2010): The amelioration of the Muscat d'Adda variety through clonal selection. Annals. Food Science and Technology, 11 (2): $74-78$.

Bakonyi, K. (1968): Olasz rizling szőlőfajta klónszelektálása és klónjainak értékelése. A Keszthelyi Agrártudományi Föiskola Közleményei. Keszthely, 10 (5): 3-43.

Bálint, A. (1976): A növénynemesítés alapjai. Mezögazdasági Kiadó. Budapest, (239): $65-71$.

Becker, H. \& Sievers, E. (1978): Leistungssteigerung durch Klonenselektion. Der Deutsche Weinbau. Waldkirch. 33 (25): 3 -6.

Becker, H. (1990): A szőlő klónszelekciója a Német Szövetségi Köztársaságban összehasonlítva a többi országgal. Szölötermesztés és Borászat. 12 (1-2): 7-10.

Bleser, E., Konrad, H. \& Rühl, E.H. (2004): Prespektiven der Klonenzüchtung. Deutsches Weinbau Jahrbuch (2005). Eugen Ulmer GmbH and Co. Stuttgart, (260): 116-121.

Bouquet, A. (1989): Culture in vitro de la vigne. Attention aux mauvaises surprises! Progre's Agricole et Viticole. 106 (13-14): 303-306.

Bovey, R., Rochaix, M. \& Simon, J.L.(1973): La sélection phytosanitaire de la vigne. Bulletin de l'O.I.V. Paris. 46 (514) 1077-1093.

Bögre, J. \& Dohy, J. (1992): Fékevesztett mutációk - „új lamarckizmus"? Magyar Tudomány, (8) 952-958.

Brückbauer, H. \& Rüdel, M. (1971): Die Viruskrankheiten der Rebe. Verlag Eugen Ulmer. Stuttgart, (119) 20-83.

Butiuc-Keul, A.L., Coste, A., Oltean, B., Craciunas, C.,
Halmagyi, A., Delin, C., Farago, M., Iliescu, M. \& Iuoras, R. (2009): 'In vitro' clonal propagation of several grapevine cultivars. Acta Horticulturae. Leuven, (843): $151-156$.

Calo, A. (1987): La selezione clonale. Rivista di Viticoltura e di Enologia. Conegliano, (10): 443-448.

Calo, A., Costacurta, A. \& Egger, E. (1978): Klonenselektion und Erzeugung von Rebenpflanzgut in Italien. XV. Geisenheimer Rebenveredlertagung. Heft 11. Johnen-Druck. Bernkastel - Kues (183): 20 -37.

Castro, I., Leal, F., Guedes-Pinto, H., EirasDias, J., Veloso, M. \& Pinto-Carnide, O. (2009): Genomic variability in grapevine cultivars assussed by molecular markers. Acta Horticulturae. Leuven, (827).

Cindrić, P. (1981): Prilog poznavanju vrednosti nekih klonova sorte italijanski rizling. Vinogradarstvo $i$ Vinarstvo. Beograd. 14 (35-36): 73-77.

Cindrić, P., Kovać, V. \& Vukmirović, N. (1987): Klonenselektion der Sorte Welschriesling. Schweizerische landwirtschaftliche Forschung (401) Heft 3, (26): $276-278$.

Cirami, R.M., McCarthy, M.G., Furkaliev, D.G. \& Ewart, A.J.W. (1987): Clonal Selection of Riesling in South Australia. Schweizerische landwirtschaftliche Forschung (401) Heft 3, (26): 288-290.

Craciunas, G., Coste, A., Oltean, B., Farago, M., Iliescu, M., Iuoras, R. \& Butiuc-Keul, A.L. (2009): Genetic Stability of Several Cultivars of Grapevine cultivated ,in vitro”. Acta Horticulturae (812): 515-520.

Cretazzo, E., Meneghetti, S., Andres, M.T. de, Gaforio, L., Frare, E. \& Cifre, J. (2010): CLone differentiation and varietal identification by means of SSR, AFLP, SAMPL and M_AFLP in order to assess the clonal selection of grapevine: the case study of Manto, Negro, Callet und Moll, autochtonous cultivars of Majorca. Annals of Applied Biology. 157 (2): 213-227.

Currle, O., Bauer, O., Hofäcker, W., Schumann, F. \& Fisch, W. (1983): Biologie der Rebe. D. Meininger Verlg und Druckerei $\mathrm{GmbH}$ (311): 248-277.

Fischer, M. (2006): ESCA der Weinrebe - eine Krenkheit auf dem Vormarsch? Deutsches Weinbau Jahrbuch. Verlag Eugen Ulmer. Stuttgart, (275): 87-94.

Füri, J. \& Németh, M. (1972): Stand der Leistungsselektion bei der Rebe in Ungarn. Die Wein-Wissenschaft. Wiesbaden.27 (3-4): 76-96.

Füri, J., Hajdu, E. \& Csenki, R. (1987): Genetische Selektion in den Weintraubensorten Lindenblättriger, Irsai Olivér und Steinschiller. Schweizerische landwirtschaftliche Forschung. Heft 3, (401) (26): 282-287.

Hajdu, E. (1989): Selection Advance and Environmental Variance in the clonal selection of the Wine Grape Varieties Kövidinka. Proceedings of the 5th International. Symposium on Grape Breeding. Vitis Special Issue. 1990. Landau. 478-484.

Hajdu, E. (1990): A klónszelekció kecskeméti eredményei és kutatási feladatai. Szölötermesztés és Borászat. Kecskemét. 12 (1-2): 10-14. 
Hajdu, E. (1993): Szőlőfajták klónszelekciója. MTA Kandidátusi ért, (192)

Hajdu, E. (2011): Szőlőtermesztésben előforduló fejlődési zavarok és gyógyításuk in: Terbe, I., Slezák, K. \& Kappel, N. (2011): Kertészeti és szántóföldi növények fejlődési rendellenességei. Mezögazda Kiadó. Budapest, (312): 179-192.

Hajdu, E., Kőrösi, F., Jezierska \& Szabó, E. (1992): Borszőlőfajták sugárérzékenységének tesztelése. Élelmiszerfizikai Közlemények 1992/2a Kertészeti és Élelmiszeripari Egyetem Közleményei XVI.

Hartmair, V. (1973): Phytosanitäre Massnahmen im Rahmen der Rebenzüchtung. Der Winzer. Wein. 29 (6): 146-149.

Hoffmann, P., Blaich, R. \& Forneck, A. (2009): Retrotransposonbased mutations in clones of Pinot varieties. Acta Horticulturae. Belgium, (827): 83-86.

Ivanov, J., Zankov, Z. \& Valcev, V. (1970): Génétique et amélioration de la vigne Rapport Bulgare. Bulletin de l'O.I.V. Paris (43): 715-732.

Kiss, E. (1990): A klónszelekció eredményei Badacsonyban. Szölötermesztés és Borászat. Kecskemét. 12 (1-2): 15-17.

Kontic, J.K., Pejic, I., Maletic, E., Sladonja, B., Poljuha, D., Vokurka, A., Zdumic, G., Preiner, D., Simon, S. \& Rühl, E. (2009): Virus diseases screening in clonal selection of Croation grapevine cultivars. Acta Horticulturae. Belgium, (827): 623-626.

Kozma, P. (1957): Így szelektáljuk a Kadarkát. FM Egyetemi Nyomda. Budapest, (36)

Legin, R. (1973): Erfahrungen mit der Gesundheitselektion im französischen Weinbau, sowie deren Organisation. Weinbau und Keller. Bernkastel-Kues. 20 (19): 351-353.

Lehoczky, J. (1968): Baktériumos golyvásodás rosszindulatú folyamata a szőlőn. Országos Szölészeti és Borászati Kutató Intézet Évkönyve. Mezögazdasági Kiadó. Budapest, (13): 115-124.

Loureiro, M.D., Moreno-Sanz, P. \& Suarez, B. (2011): Clonal presentation of grapevine cultivars of the appellation 'Cangas Quality Wine' (Asturias, Spain). Horticultural Science. Prague. 38 (2): $71-80$.
Luntz, O. (1962): Szelektáljuk az Ezerjó szőlőfajtát is! Kertészet és Szölészet. Budapest,11 (17): 16.

Malenin, I. (1971): Borbata sz baktyerialnija rak po lozata. Raszt. Zast. Szofija. 19 (5): $10-12$.

Németh, M. (1958): A szőlő klónszelekciós nemesítéséről. Agrártudomány. Budapest. 43-49.

Pétervári, A. (2000): dr. Bakonyi Károly szőlőnemesítő. Georgikon Kiskönyvtár. Tudománytörténeti füzet. Keszthely, (59): 8.

Pouget, R. (1978): Über die Züchtung neuer Unterlagssorten in Frankreich. XV. Geisenheimer Rebenveredlertagung 1978. Heft 11. Johnen-Druck. Bernkastel-Kues, (183): 54-63.

Rédei, P.Gy. (1987): Szelekció. Genetika II. rész. Mezőgazdasági Kiadó - Gondolat. Budapest, (830): 651-701.

Sartorius, O. (1928): Über die wissenschaftlichen Grundlagen der Rebenselektion in reinen Beständen. Zeitschrift für Pflanzenzüchtung (13): 79-86.

Scarabrelli, G., Ferroni, G., Onofrio, D., Borgo, M., Porro, D. \& Stefanini, M. (2003): Clonal selection of Vermentino Grapevine Variety in the Tuscan Coastal Area. Proceedings of the 8th Int. Conf. on Grape Genetics and Breeging. Kecskemét. Acta Horticulture 603. Leuven. 2 (786): 641-649.

Schöffling, H. \& Stellmach, G. (1993): Klonzüchtung bei Weinreben in Deutschland. Waldkircher Verlag, (818): 115-146.

Steingruber, P. (1933): Die Grenzen des Erfolges bei Selection im Weinbau. Gartenbauwissenschaft (1950): 178-195.

Stellmach, G. (1972): Altes und Neues aus Kloneselektion und Erhaltungszüchtung bei Reben. Weinberg und Keller. BernkastelKues. 19 (2): 84-104.

Stenkapm, S., Ottaviano, F., Becker, M., Forneck, A. \& Blaich, R. (2004): Chimären - ein verbreitetes Phänomen im Weinbau. Deutsches Weinbau Jahrbuch 2005. Eugen Ulmer GmbH und Co. Stuttgart, (260): 109-115.

Valat, C. (1975): Anwendungstechnik der Klonenselektion in Frankreich-Organisation der Selektion und der Vermehrung. XIV. Geisenheimer Rebenveredlertagung. Heft 10. Weinberg und Keller Verlag. Bernkastel-Kues, (147): 94-102. 